\title{
Average wage, qualification of the workforce and export performance in German enterprises: evidence from KombiFiD data
}

\author{
Joachim Wagner
}

Accepted: 30 April 2012 / Published online: 29 June 2012

(C) Institut für Arbeitsmarkt- und Berufsforschung 2012

\begin{abstract}
Empirical investigations with enterprise level data from official statistics often use the average wage as a proxy variable for the qualification of the workforce, mostly due to the lack of detailed information on the qualification of the employees. This paper uses unique newly available data for German enterprises from the KombiFiD project that for the first time combine information from the statistics of employees covered by social security and information from surveys performed by the Statistical Offices to look at the quality of this proxy variable by investigating the link between the average wage in a firm and the qualification of the workforce. Furthermore, it demonstrates that detailed information on the qualification of the workforce sheds new light on the role of highly qualified employees for success on export markets that is not revealed by the average wage as a proxy variable. Based on the results of this paper it is argued that combined firm level data that stem from different data producers should be widely accessible for research.
\end{abstract}

Keywords Qualification of workforce · average wage · export · firm level data

JEL Classification C81 $\cdot$ F14 $\cdot$ J31

\section{Durchschnittslohn, Belegschaftsqualifikation und} Exporttätigkeit in deutschen Unternehmen: Empirische Befunde mit den KombiFiD-Daten

Zusammenfassung Empirische Untersuchungen mit Firmendaten der amtlichen Statistik verwenden oft den Durchschnittslohn als eine Proxy-Variable für die Qualifikation

Prof. Dr. J. Wagner $(\bowtie)$

Institute of Economics, Leuphana University Lueneburg,

P.O. Box 2440, 21314 Lueneburg, Germany

e-mail: wagner@leuphana.de der Belegschaft. Der Grund dafür liegt zumeist darin, dass es in den Daten keine detaillierten Informationen über die Belegschaftsqualifikation gibt. Dieser Beitrag nutzt einen einzigartigen neu verfügbaren Datensatz für deutsche Industrieunternehmen aus dem KombiFiD-Projekt. In diesem Projekt wurden zum ersten Mal Informationen aus der Statistik der sozialversicherungspflichtig Beschäftigten mit Daten aus Erhebungen der Statischen Ämter kombiniert. Diese kombinierten Daten werden herangezogen um die Qualität der Proxyvariable Durchschnittslohnsatz zu überprüfen. Hierzu wird zunächst der Zusammenhang zwischen dem Durchschnittslohnsatz in einer Unternehmung und der Qualifikation der Belegschaft untersucht. Darüber hinaus wird gezeigt, dass detaillierte Angaben über die Qualifikation der Arbeitskräfte zu neuen Erkenntnissen über die Rolle der hochqualifizierten Beschäftigten für den Erfolg auf Exportmärkten führen, die sich aus einer Betrachtung der durchschnittlichen Lohnhöhe in der Firma nicht gewinnen lassen. Dieser Beitrag zeigt, dass Datensätze, in denen Unternehmensinformationen aus verschiedenen Quellen kombiniert werden, für wissenschaftliche Untersuchungen breit verfügbar gemacht werden sollten.

\section{Motivation}

Empirical investigations with firm level data from official statistics often use the average wage paid in a firm, computed as the total wage bill over the number of employees, as a proxy variable for human capital intensity of production. The information on the number of employees and on the wage bill is widely available in surveys of firms conducted by the statistical offices all over the world. More detailed information on the qualification of the workforce (like 
the share of employees with a certain level of education attained or vocational training concluded), however, is only rarely available at the firm level in this type of data ${ }^{1}$ (see Syverson 2011, p. 340).

As a case in point, and to motivate this study by pointing to a potential pitfall caused by using the average wage as a proxy variable for human capital intensity, consider a recent study on the links between firm characteristics and exports in enterprises from German manufacturing industries (Wagner 2011a). Germany is one of the leading actors on the world market for manufactured goods but not every firm from a manufacturing industry in Germany is an exporter. In 2006 the share of exporters in all enterprises was 69 percent in West Germany and 52 percent in East Germany. ${ }^{2}$ Reliable information on the characteristics of exporting and non-exporting firms and on the links between firm characteristics and the share of exports in total sales is important to guide theorists and policy makers in an evidence based way. In Wagner (2011a) recently released rich high quality data for a large representative panel of enterprises from German manufacturing industries are used to investigate the links between firm characteristics and export activities, and a decisive role of human capital intensity for exporting is found.

Unfortunately, in the enterprise level data used in this study there is no better proxy for human capital intensity than the average wage per employee in a firm. For example, the data has no information on the share of employees with a university degree or the share of employees that successfully passed the exams following apprenticeship. ${ }^{3}$ To justify the use of the average wage in a firm as a proxy variable for human capital intensity in the absence of more direct measures it is argued that although qualification of the work force is not the only determinant of the average wage in a firm it can be expected to be highly positively correlated with it. Furthermore, it is pointed out that in the empirical models that

\footnotetext{
${ }^{1}$ Note that establishment surveys with voluntary participation of the firms (and linked employer-employee data that use information from these surveys) usually collect information on the qualification of the workforce at a detailed level; for Germany, see the IAB Establishment Panel (Fischer et al. 2009) and the linked employer-employee data from the LIAB (Alda et al. 2005).

${ }^{2}$ Figures are based on the author's own calculations and refer to enterprises with at least 20 persons working in it; see Wagner (2011a).

${ }^{3}$ The distinction between blue collar workers and white collar workers that is often used in the literature (for Germany, see e.g. Bernard and Wagner 2001) is no way to proxy human capital intensity for two reasons. First, often blue collar workers are high qualified skilled employees with apprenticeship (so-called Facharbeiter) while white collar workers include many unskilled employees. Second, the distinction between blue collar workers (Arbeiter) and white collar workers (Angestellte) is no longer used in Germany after a reform of the pension system; in the data from official statistics, for example, there is no separate information on wages (for blue collar workers) and salaries (for white collar employees) from the reporting year 2006 onwards.
}

link wage per employee to exporting both firm size and industry affiliation are included and, therefore, both firm-size wage differentials and inter-industry wage differentials are controlled for.

While due to the lack of detailed information on the qualification of the employees this approach is widely used in the literature it is not without problems especially when it comes to the analysis of the links between exports and human capital intensity. It is a stylized fact found in many micro-econometric studies from a number of countries that exporters pay higher wages (see Schank et al. 2007 for a survey). Recent studies using linked employer-employee panel data show that wage differences between exporters and nonexporters become smaller but do not completely vanish once observable and unobservable characteristics of the employees and of the workplace are controlled for. ${ }^{4}$ Therefore, any empirical model that uses the average wage in a firm as a proxy variable for human capital intensity of production to investigate the link between firm characteristics and the propensity to export suffers from an endogeneity problemthe higher the wage per employee the higher is the probability that the firm is an exporter not only because more human capital intensive firms have a higher probability to export but also because a firm that exports has a higher wage per employee irrespective of the (observed and unobserved) qualification of the work force!

This paper makes two contributions to the literature. First, it presents empirical evidence on the quality of the average wage in a firm as a proxy variable for the qualification of the employees. Second, it demonstrates that detailed information on the qualification of the workforce sheds new light on the role of highly qualified employees for success on export markets that is not revealed by the average wage as a proxy variable. In the empirical investigations it uses unique newly available data for German enterprises from the KombiFiD project (discussed in detail below) that for the first time combine information from the statistics of employees covered by social security and information from surveys performed by the Statistical Offices. Based on the results of this paper it is argued that combined firm level data that stem from different data producers should be widely accessible for research.

The rest of the paper is organized as follows. Section 2 describes the data used and the definition of variables. Section 3 looks at the link between the average wage in a firm

\footnotetext{
${ }^{4}$ See Schank et al. (2007) for Germany; other studies using linked employer-employee panel data to investigate the link between individual wages of the employees and export activities of the employer [including Munch and Skaksen 2008 and Klein et al. 2010] are surveyed in Wagner (2012). Note that Schank et al. (2010) find that higher wages in exporting firms are due to self-selection of more productive, better paying firms into export markets; they are not caused by export activities.
} 
and the qualification of the workforce. Section 4 compares results from empirical models for export participation and for the share of exports in total sales that use either the average wage of a firm or information on the qualification of the workforce to measure the human capital intensity of the production. Section 5 concludes.

\section{Data and definition of variables}

The empirical investigation uses data for enterprises ${ }^{5}$ from manufacturing industries that come from two sources. The first source is the so-called AFiD-Panel Industrial Enterprises that combines information about firms from manufacturing industries that stem from various surveys conducted by the German statistical offices (see Malchin and Voshage 2009 for details). These data are the source for the following variables:

- Average wage in a firm, defined as the annual sum of wages paid (without social security contributions paid by the firm) over the number of persons working in the firm, and measured in Euro.

- $R \& D$ intensity, measured by expenditures on research and development over total turnover (in percent).

- Share of exports in total sales, measured as exports over total turnover (in percent).

- Capital intensity, measured as value of physical capital per person working in the firm. ${ }^{6}$

- Firm size, measured by the number of persons working in the firm.

- Industry affiliation of a firm, recorded at the four-digit level.

The second source of data is the Establishment History Panel (Betriebs-Historik-Panel). ${ }^{7}$ Details aside, this data set

\footnotetext{
${ }^{5}$ Data are for legal units (enterprises, or Unternehmen), not for local production units (establishments, or Betriebe). In this paper we use the term firm as a synonym for enterprise.

${ }^{6}$ Note that information on physical capital used in the firm is not available in the data. Annual data for investments are available. A careful inspection of these investment data revealed that they should not be used to construct estimates of the capital stock of the firm by using the perpetual inventory method. The crucial problem here lies in the fact that investment at the firm level tends to be highly volatile. Often very high values in some year and very low values (or no investments at all) in some other year are reported, and this leads to rather different values for the capital stock proxy variable depending on the year(s) used. A proxy for the physical capital used in a firm can be constructed using information based on the amount of depreciation reported in the cost structure survey (see Wagner 2010 for details). This proxy variable is used here.

${ }^{7}$ For an introduction to the Establishment History Panel see Spengler (2008); a detailed description of the current version is Hethey-Maier and Seth (2010).
}

is built from individual level information for employees covered by social security. ${ }^{8}$ In a first step for each year from 1975 onwards information for all employees working in a local production unit (establishment) was aggregated, and this is the standard version of the Establishment History Panel. In this study a different version of the Establishment History Panel is used. Here for multi-establishment enterprises information from all establishments of the enterprise was aggregated in a second step. The result is a data set with detailed information about the characteristics of the employees (covered by social security) in each enterprise in a year.

Information reported to the social security system includes, among others, the qualification (educational level attained and vocational training concluded). The following variables based on this information are used:

- Share of medium qualified employees is defined as the total number of employees (covered by social security) with either the high-school diploma (Abitur) as the highest educational level attained or with vocational training concluded over the total number of employees (covered by social security) in an enterprise; the share is measured as a percentage.

- Share of highly qualified employees is defined as the total number of employees with a polytech or university degree over the total number of employees (covered by social security) in an enterprise; the share is measured as a percentage.

The AFiD-Panel Industrial Enterprises is prepared by the German statistical offices. The data can be accessed for scientific research via the Research Data Centres of the Federal Statistical Office and the Statistical Offices of the Federal States (see Malchin and Voshage 2009). The Establishment History Panel is build from administrative data by the Research Data Centre of the Federal Employment Agency at the Institute for Employment Research. The data can be accessed via this Research Data Centre for scientific research (see Spengler 2008).

Linking these confidential firm level data across the borders of the data producers, however, is difficult. Details aside, it is technically not easy (but not impossible either) and it is legal only if the firm agreed in written form. The basic idea of the project KombiFiD (an acronym that stands for Kombinierte Firmendaten für Deutschland, or combined firm level data for Germany) that is in detail described on the

\footnotetext{
8“All employees who are subject to at least one of the following compulsory insurances are liable to social security: health insurance, longterm care insurance, pension insurance, unemployment and accident insurance. However, not liable to social security and thus not included in the data are civil servants, conscripts, those doing alternative civilian service, self-employed, judges, scholars, students, pensioners, clergy and others" (Spengler 2008, p. 502).
} 
web (see www.kombifid.de) is to ask a large sample of firms from all parts of the German economy to agree to match confidential micro data for these firms that are kept separately by three data producers (the Statistical Offices, the Federal Employment Agency, and the German Central Bank) in one data set. These matched data are made available for scientific research while strictly obeying the data protection law, i.e. without revealing micro level information to researchers outside the data producing agencies. In KombiFiD 54,960 firms were asked to agree in written form to merge firm level data from various surveys and administrative data for the reporting years 2003 to 2006. 30,944 firms replied and 16,571 agreed. These 16,571 firms are in the KombiFiD Agreement Sample.

The sample of enterprises used in the empirical investigation performed here consists of all firms from manufacturing industries in West Germany ${ }^{9}$ in the KombiFiD Agreement Sample for which information from both data sources ${ }^{10}$ the AFiD-Panel Industrial Enterprises and the Establishment History Panel-could be linked in the KombiFiD project for 2006. ${ }^{11}$ Enterprises that do not have complete information for all variables were dropped from the computations. This leads to a data set with 4,588 observations.

\footnotetext{
${ }^{9}$ The sample is limited to firms from West Germany. There are large differences between enterprises from West Germany and the former communist East Germany even many years after the unification in 1990. Therefore, an empirical study should be performed separately for both parts of Germany. The KombiFiD Agreement Sample for East German manufacturing firms, however, contains only a small number of firms, and this sample turned out to be not representative for the population of firms in a replication study that compares results based on the complete cost structure survey data and data from the KombiFiD Agreement Sample (see Wagner 2011b). Note that the share of exporters in West Germany in the KombiFiD Agreement Sample is larger (about $83 \%$ ) than the share of exporters among all manufacturing enterprises $(69 \%)$ mentioned in the introduction. This is due to the fact that the AFiD-Panel Industrial Enterprises that is a basis for the KombiFiD-sample by construction oversamples larger firms. Furthermore, the average number of employees tends to be somewhat larger in the KombiFiD Agreement Sample than in the AFiD-Panel Industrial Enterprises. For West Germany, however, the data from the KombiFiD Agreement sample can be regarded as representative data, especially if firm size is controlled for in an empirical model; for details see Wagner (2011b).

${ }^{10}$ Data on foreign direct investments and balance sheet data from the German Central Bank are not used in this study. The KombiFiD sample including data from this source is small and consists mostly of large exporting firms; therefore, these data are not suited for an empirical investigation of export participation and export performance.

${ }^{11}$ All variables are extremely highly positively correlated over the four years covered by the KombiFiD sample. The within-variation is very small compared to the between variation, and it is too small to produce reliable coefficient estimates in a model that controls for unobserved firm heterogeneity by using pooled data and adding fixed firm effects (see Wagner 2011a for a comprehensive discussion of this problem and results from fixed-effects regressions). Therefore, this study uses cross-section data for the last year covered in the KombiFiD-data only.
}

\section{Average wage and qualification of the workforce in the firm}

In the first step of the empirical investigation of the quality of the average wage in a firm as a proxy variable for the qualification of the employees we will look at the link between the average wage and the shares of medium qualified employees (which either have a high-school diploma (Abitur) as the highest educational level attained or which successfully concluded vocational training) and highly qualified employees (with a polytech or university degree). Descriptive statistics for firms from West Germany in $2006^{12}$ in Table 1 show that the share of highly qualified employees tends to be rather small-it is less than four percent in the median firm-while a large fraction of employees is classified as medium qualified (two thirds of all employees in the median firm are from this group). As expected, the correlation of the share of employees from both of these groups with the average wage in a firm is positive, and it is much higher for the share of highly qualified employees. Note that both shares of employees are uncorrelated in the firms in the sample.

A simple OLS regression of the average wage in a firm on the share of highly qualified employees and the share of medium qualified employees (plus a constant) points to a statistically highly significant positive link between the qualification level of the workforce and the wage level (see results for model 1 reported in Table 2). As expected, the estimated regression coefficient is considerable larger (by a factor five) for the share of highly qualified employees compared to the estimated coefficient for the share of medium qualified employees. The same results are found when firm size (measured by the number of employees and its squared value) and industry (measured by dummy-variables at the 4 digit industry level) are controlled for to take care of firmsize wage effects and industry wage effect (see results for model 2).

The $R^{2}$-value for model 1 shows that some 30 percent of the variation of the average wage between the firms in the sample can be explained by the variation of the qualification of the employees. If the empirical model is augmented by firm size and industry affiliation the proportion of the variation of the average wage explained by the variation of the variables included in the model raises to about half of the total variation.

These results indicate that the average wage in a firm can indeed be regarded as a proxy variable for the qualification level of the workforce - the higher the share of qualified em-

\footnotetext{
${ }^{12}$ The shares of employees from various groups are highly stable over time; therefore, results are reported for the latest year covered by the KombiFiD sample only.
} 
Table 1 Descriptive statistics for the sample of enterprises: West Germany, manufacturing industries, 2006

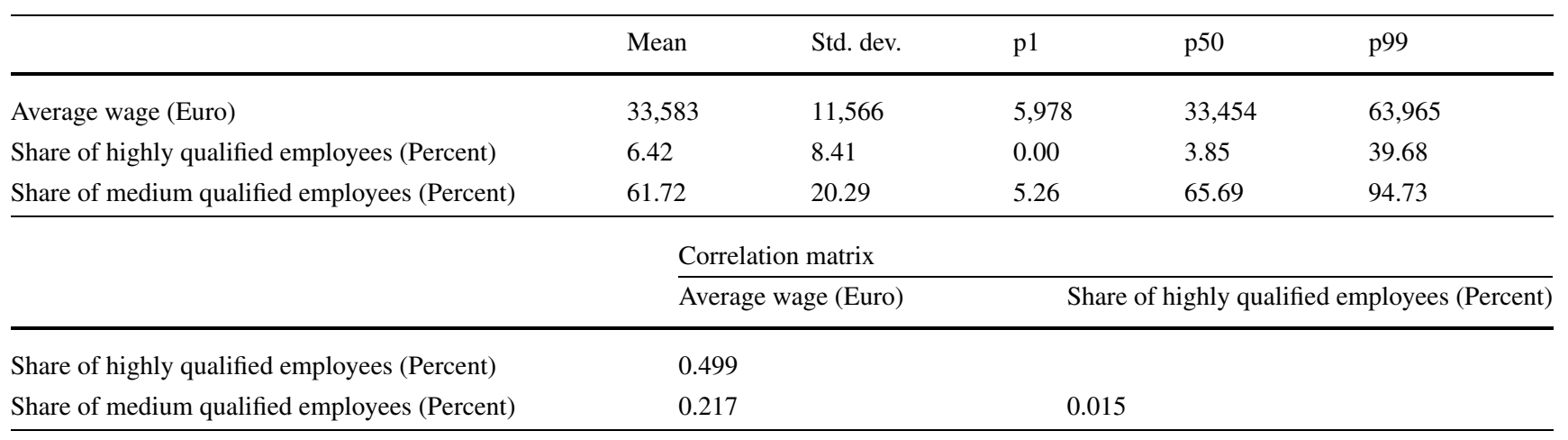

Note: For a definition of the variables see text. p1, p50 and p99 refer to the 1st , 50th and 99th percentile. The number of observations is 4,588

Table 2 Average wage and qualification of the workforce in a firm: West Germany, manufacturing industries, 2006

\begin{tabular}{llll}
\hline Independent variable & & \multicolumn{2}{l}{ Estimation method: OLS Dependent variable: Average wage (Euro) } \\
\cline { 2 - 3 } & & Model 1 & Model 2 \\
\hline Share of highly qualified employees (Percent) & $\beta$ & 682.15 & 0.000 \\
Share of medium qualified employees (Percent) & $p$ & 0.000 & 82.04 \\
& $p$ & 119.36 & 0.000 \\
Firm size (number of employees) & $\beta$ & 0.000 & 0.621 \\
& $P$ & & 0.000 \\
Firm size (squared) & $\beta$ & & $-4.17 \mathrm{e}-6$ \\
& $p$ & & 0.003 \\
4digit industry dummy variables & & Not included & Included \\
Constant & $\beta$ & $21,832.53$ & $5,426.15$ \\
& $P$ & 0.000 & 0.281
\end{tabular}

Note: For a definition of the variables see text. $\beta$ is the estimated regression coefficient, $p$ is the prob-value. A robust estimator of variance was used

ployees, the higher is the average wage (controlling for firmsize and industry effects, too). The fit of the empirical model, however, is far from perfect. To state it differently, the average wage measures other characteristics of the firm and its environment besides the qualification of the workforce, too. ${ }^{13}$

\footnotetext{
${ }^{13} \mathrm{~A}$ discussion of the reasons for differences in the average wage of a workforce with identical qualification is beyond the scope of this paper. Possible reasons include a higher average wage in a firm that earns higher profit due to product market conditions and that shares part of the extra profits with its employees, and efficiency wages paid by a firm to motivate employees to work harder.
}

\section{Application: on the role of human capital intensity for the export performance of manufacturing firms in West Germany}

To shed more light on the usefulness of the average wage in a firm as a proxy variable for the qualification of the workforce this section compares results from empirical models for export participation and for the share of exports in total sales that use either the average wage of a firm or information on the shares of medium and highly qualified employees as a measure of the human capital intensity of production.

The empirical models used in this exercise take a clue from a recent empirical study on firm characteristics and ex- 
Table 3 Descriptive statistics for the sample of enterprises by exporter status: West Germany, manufacturing industries, 2006

\begin{tabular}{|c|c|c|c|c|c|c|}
\hline & \multicolumn{2}{|c|}{ Exporter } & \multicolumn{2}{|c|}{ Non-exporter } & \multirow{2}{*}{$\begin{array}{l}t \text {-Test } \\
\text { (prob-value) }\end{array}$} & \multirow{2}{*}{$\begin{array}{l}\text { K-S-Test } \\
\text { (prob-value) }\end{array}$} \\
\hline & Mean & Std. dev. & Mean & Std. dev. & & \\
\hline Average wage (Euro) & 35,160 & 178.47 & 26,776 & 453.20 & 0.000 & 0.000 \\
\hline Share of highly qualified employees (Percent) & 7.11 & 0.14 & 3.57 & 0.25 & 0.000 & 0.000 \\
\hline Share of medium qualified employees (Percent) & 61.98 & 0.32 & 60.60 & 0.84 & 0.1243 & * \\
\hline Capital intensity (Euro) & 90,908 & 1,956 & 79,373 & 4,552 & 0.020 & 0.000 \\
\hline R\&D intensity (Percent) & 1.28 & 0.05 & 0.19 & 0.05 & 0.000 & 0.000 \\
\hline Firm size (Number of persons) & 477.35 & 63.93 & 163.58 & 10.32 & 0.000 & 0.000 \\
\hline Share of Exports in total sales (Percent) & 34.82 & 25.42 & & & & \\
\hline
\end{tabular}

Note: For a definition of the variables see text. The number of observations is 4,431; 742 (or $16.75 \%$ ) of these enterprises were non-exporters. The prob-value of the $t$-Test is for the null-hypothesis of no difference in mean values (assuming unequal variances in the two groups of firms); a prob-value of the Kolmogorov-Smirnov Test (K-S-Test) that is 0.05 or smaller indicates that the distribution of the variable for the exporters first-order stochastically dominates the distribution of the variable for the non-exporters

* Indicates a case where the results of the K-S-Test gives inconclusive results—neither the null-hypothesis that the distribution of the variable for the exporters first-order stochastically dominates the distribution of the variable for the non-exporters nor the null-hypothesis that the distribution of the variable for the non-exporters first-order stochastically dominates the distribution of the variable for the exporters can be rejected at an error level of 5 percent or less

ports (Wagner 2011a). A comprehensive theoretical model for the export decision of a firm that discriminates between exporters and non-exporters and that explains the share of exports in total sales is lacking. Therefore, the empirical models used in this study are based on elements of a theory of the exporting firm. ${ }^{14}$

A starting point is the stylized fact that firm size and exports are positively related. This positive link between exports and firm size is due to fixed costs of exporting and efficiency advantages of larger firms due to scale economies, advantages of specialization in management and better conditions on the markets for inputs. Large firms can be expected to have cost advantages on credit markets while small firms often face higher restrictions on the capital market leading to a higher risk of insolvency and illiquidity. Furthermore, there might be disadvantages of small firms in the competition for highly qualified employees. There are limits to the advantage of size, because coordination costs mount as the scale of operations increases, and at some point any further expansion might cease to be profitable. Therefore, a positive relationship between firm size and exports, at least up to a point, is expected.

\footnotetext{
${ }^{14}$ The theoretical arguments are standard in the literature on the microeconometrics of exports (see Wagner 2011a and the literature cited therein). Therefore, the discussion can be brief here. Note that the role of productivity for exporting that is at the centre of the new trade theory and the micro-econometric studies inspired by these models is not considered here: see Melitz (2003) for the canonical theoretical model, Helpman (2011, Ch. 5) for a survey of the theory, Wagner (2007) for a survey of empirical studies and Wagner (2011a) for a discussion of the links between the variables included in the empirical model used in this study and firm productivity.
}

Further elements of an empirical model to explain the export performance of firms can be taken from the theory of international trade. Countries have a comparative advantage in the production of goods that use the relative abundant factors of production relatively intensively. Given that Germany is relatively rich in physical and human capital and one of the technologically leading countries, firms that use physical and human capital intensively and that are active in $\mathrm{R} \& \mathrm{D}$ can be expected to have a comparative advantage on the international market.

Here, human capital intensity is measured by either the average wage in a firm or by the shares of medium and highly qualified employees; physical capital intensity is measured as value of physical capital per person working in the firm; R\&D intensity is measured by expenditures on research and development over total turnover; Firm size is measured by the number of persons working in the firm; the industry affiliation of a firm is recorded at the four-digit level and a set of dummy variables for the industries is included in the empirical models; the share of exports in total sales is measured as exports over total turnover. ${ }^{15}$

Table 3 shows that on average exporters are larger, use more physical capital per employee, have a higher value of human capital intensity (measured by either the average wage in the firm or the share of highly qualified employees) and are more R\&D intensive. All these differences between exporters and non-exporters are highly statistically significant and large from an economic point of view. Furthermore, results of the Kolmogorov-Smirnov test indicate that these differences are not only observed at the mean; the distribu-

\footnotetext{
${ }^{15}$ For details and the sources of variables see Sect. 2.
} 
tion of these firm characteristics for the exporters first-order stochastically dominates the distribution of the firm characteristics for the non-exporters. ${ }^{16}$ These findings are in line with the theoretical considerations and with results reported for Germany for other samples of firms. Note that the share of medium qualified employees does not differ statistically and economically significantly between the two groups of firms.

Table 4 reports results for the estimation of empirical models that link firm characteristics ${ }^{17}$ to the probability that a firm is an exporter and to the share of exports in total sales of a firm. ${ }^{18}$ The average wage in a firm and the share of highly qualified employees are both positively linked with the propensity to export-the estimated probit regression coefficients are positive and highly statistically significant. Note that this is not the case for the share of medium qualified employees. In line with the descriptive results discussed above the probit estimates show that the share of medium qualified employees in a firm and the propensity to export of the firm are unrelated.

Results from empirical models for the share of exports in total sales point to a positive link between export activity and human capital intensity, too. The estimated regression coefficients for the average wage in a firm are positive and highly statistically significant irrespective of the estimation

\footnotetext{
${ }^{16}$ The non-parametric Kolmogorov-Smirnov test for first order stochastic dominance of one distribution over another was introduced into the empirical literature on exports by Delgado et al. (2002). Let $F$ and $G$ denote the cumulative distribution functions of a variable for two groups of firms, exporters and non-exporters. First order stochastic dominance of $F$ relative to $G$ is given if $F(z)-G(z)$ is less or equal zero for all $z$ with strict inequality for some $z$. Given two independent random samples of firms from each group, the hypothesis that $F$ is to the right of $G$ can be tested by the Kolmogorov-Smirnov test based on the empirical distribution functions for $F$ and $G$ in the samples (for details, see Conover 1999, p. 456ff.).

${ }^{17}$ Given the focus of this paper the discussion of the estimation results is limited to the human capital variables; for a broader discussion of the results see Wagner (2011a).

${ }^{18}$ The KombiFiD Agreement Sample has complete information for 4,588 firms. These observations are used to compute the results reported in Table 2. The models in Table 4 include a variable that is not part of the original KombiFiD Agreement Sample but that is computed based on data from this sample and on data from external sourcescapital intensity. As stated in Sect. 2 when describing the data used, information on physical capital used in the firm is not available in the data. A proxy for the physical capital used in a firm can be constructed using information based on the amount of depreciation reported in the cost structure survey (see Wagner 2010 for details). This proxy variable is used here, but it could not be computed for all 4,588 firms-only for the 4,431 firms used in the OLS and Fractional logit estimates in Table 4. The Probit regressions include 232 4-digit industry dummy variables. Stata drops all observations from industries where all firms were exporters in the sample used-this is the case for 98 industries with 1 to 39 observations and a total number of 822 observations. Therefore, only 3,609 observations are used in the Probit regressions.
}

method $^{19}$ used. The same holds for the estimated regression coefficients for the share of highly qualified employees, while the significance level of the positive coefficients for the share of medium qualified employees is lower (although still higher than the usual critical error level of five percent). Note that the regression coefficient of the share of medium skilled employees is much smaller than the regression coefficient of the share of highly skilled employees. These results point to a much more decisive role of highly qualified employees for success on export markets.

That said, the results indicate that irrespective of the way human capital intensity is measured a higher level of human capital intensity is positively related to exports. In line with the conclusions drawn in Sect. 3, therefore, the average wage rate can be regarded as a useful proxy variable for human capital input in a firm. The detailed information on the qualification of the employees, however, reveals that the highly qualified employees with a polytech or university degree do matter much more than the employees with a medium qualification. This important insight is only available from the new kind of data used here.

\section{Concluding remarks}

This paper demonstrates that the average wage in a firm is a useful proxy variable for the qualification of the employees. This is good news for researchers working with firm level data because information on the wage bill and the number of employees is usually available from surveys performed by statistical offices while detailed information on the qualification level of the workforce is not. ${ }^{20}$

However, this paper also shows that this detailed information on the qualification of the workforce sheds new light on the role of highly qualified employees for success on export markets that is not revealed by the average wage as a proxy variable. These results are important because reliable information on the characteristics of exporting and nonexporting firms and on the links between firm characteristics and the share of exports in total sales is crucial to understand a central dimension of firm performance. Furthermore, it can help to inform policy debates in Germany on the removal of

\footnotetext{
${ }^{19}$ Ordinary least squares (OLS) ignores the fact that the dependent variable of the empirical model is a proportion that is by definition limited between zero and one (or zero and one hundred percent) and that has a probability mass at zero (because 16.75 percent of all firms in the sample are non-exporters with a share of exports in total sales that is zero). The fractional logit estimator takes care of this; see Papke and Wooldridge (1996) for details and Wagner (2001) for the first application of this estimator to the share of exports in total sales.

${ }^{20}$ Similar evidence is reported in empirical studies on the productivity of firms where including the wage bill alone as a measure of labor inputs does almost as well as including the full array of human capital measures; see Syverson (2011, p. 340).
} 


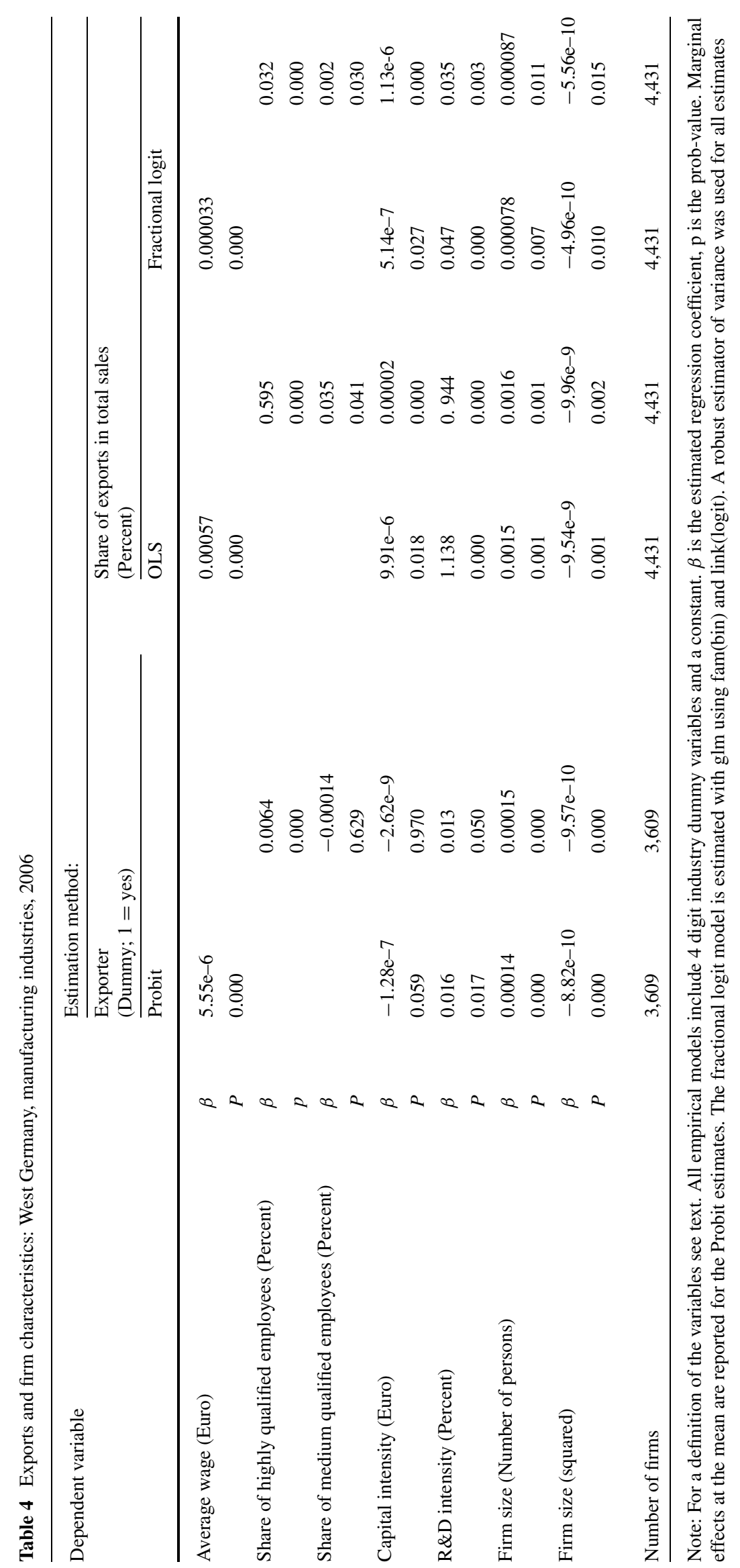


barriers to immigration for highly qualified employees from countries outside the European Union. ${ }^{21}$

The bottom line, then, is that data for German enterprises that combine information from the statistics of employees covered by social security and information from surveys performed by the Statistical Offices, and firm level data that stem from different data producers in general, should be widely accessible to foster research and to support evidencebased policy advice.

\section{Executive summary}

Empirical investigations with firm level data from official statistics often use the average wage paid in a firm, computed as the total wage bill over the number of employees, as a proxy variable for human capital intensity of production. The information on the number of employees and on the wage bill is widely available in surveys of firms conducted by the statistical offices all over the world. More detailed information on the qualification of the workforce (like the share of employees with a certain level of education attained or vocational training concluded), however, is only rarely available at the firm level in this type of data.

While due to the lack of detailed information on the qualification of the employees this approach is widely used in the literature it is not without problems especially when it comes to the analysis of the links between exports and human capital intensity. It is a stylized fact found in many micro-econometric studies from a number of countries that exporters pay higher wages. Recent studies using linked employer-employee panel data show that wage differences between exporters and non-exporters become smaller but do not completely vanish once observable and unobservable characteristics of the employees and of the workplace are controlled for. Therefore, any empirical model that uses the average wage in a firm as a proxy variable for human capital intensity of production to investigate the link between firm characteristics and the propensity to export suffers from an endogeneity problem - the higher the wage per employee the higher is the probability that the firm is an exporter not only because more human capital intensive firms have a higher probability to export but also because a firm that exports has a higher wage per employee irrespective of the (observed and unobserved) qualification of the work force!

This paper uses unique newly available data for German enterprises from the KombiFiD project that for the first time

\footnotetext{
${ }^{21} \mathrm{~A}$ case in point is the debate about the suggested introduction of a socalled „Blue Card“ that shall enable employees from countries outside the EU to work in Germany provided that they hold a university degree and have a job contract that fixes an annual wage of at least 44,000 Euro (see Frankfurter Allgemeine Zeitung, December 8, 2011, p. 11).
}

combine information from the statistics of employees covered by social security and information from surveys performed by the Statistical Offices to look at the quality of this proxy variable by investigating the link between the average wage in a firm and the qualification of the workforce. The paper demonstrates that the average wage in a firm is a useful proxy variable for the qualification of the employees. This is good news for researchers working with firm level data because information on the wage bill and the number of employees is usually available from surveys performed by statistical offices while detailed information on the qualification level of the workforce is not.

However, this paper also shows that this detailed information on the qualification of the workforce sheds new light on the role of highly qualified employees for success on export markets that is not revealed by the average wage as a proxy variable. These results are important because reliable information on the characteristics of exporting and nonexporting firms and on the links between firm characteristics and the share of exports in total sales is crucial to understand a central dimension of firm performance. Furthermore, it can help to inform policy debates in Germany on the removal of barriers to immigration for highly qualified employees from countries outside the European Union.

The bottom line, then, is that data for German enterprises that combine information from the statistics of employees covered by social security and information from surveys performed by the Statistical Offices, and firm level data that stem from different data producers in general, should be widely accessible to foster research and to support evidencebased policy advice.

\section{Kurzfassung}

Empirische Untersuchungen mit Firmendaten aus Erhebungen der amtlichen Statistik verwenden oft den Durchschnittslohnsatz in der Firma (berechnet als Lohnsumme geteilt durch die Beschäftigtenzahl) als eine Proxy-Variable für die Humankapitalintensität der Produktion. Informationen über die Anzahl der Beschäftigten und über die Lohnsumme sind üblicher Weise in Erhebungen der statistischen Ämter vorhanden. Detaillierte Informationen zur Qualifikationsstruktur der Belegschaft (wie etwa der Anteil der Beschäftigten mit einer bestimmten schulischen oder beruflichen Ausbildung) hingegen sind aus diesen Quellen nur selten verfügbar.

Auch wenn diese Vorgehensweise weit verbreitet ist, so ist sie doch insbesondere dann nicht ohne Probleme, wenn es um die Untersuchung der Zusammenhänge zwischen Exporttätigkeit und Humankapitalintensität geht. Zahlreiche empirische Studien für viele Länder zeigen, dass exportierende Firmen höhere Löhne zahlen als nicht exportierende Firmen. Neuere Untersuchungen mit Längss- 
chnittdaten für Firmen und die in ihnen tätigen Personen zeigen, dass dieses Lohndifferential zwar kleiner wird aber nicht verschwindet, wenn in Lohnschätzungen für beobachtete und unbeobachtete Eigenschaften der Firmen und der Beschäftigten kontrolliert wird. Wenn daher in einem empirischen Modell zur Erklärung des Exportverhaltens einer Firma der Durchschnittslohnsatz als ProxyVariable für die Humankapitalintensität der Produktion genutzt wird, dann liegt hier ein Endogenitätsproblem vor - die Wahrscheinlichkeit dafür, dass eine Firma exportiert, steigt mit höherem Durchschnittslohnsatz nicht nur weil humankapitalintensivere Firmen eine höhere Wahrscheinlichkeit aufweisen zu exportieren, sie steigt auch weil exportierende Firmen unabhängig von der beobachteten und der unbeobachteten Qualifikation der Belegschaft höhere Löhne zahlen!

Dieser Beitrag verwendet einen einzigartigen neu verfügbaren Datensatz für deutsche Industrieunternehmen aus dem KombiFiD-Projekt. In diesem Projekt wurden zum ersten Mal Informationen aus der Statistik der sozialversicherungspflichtig Beschäftigten mit Daten aus Erhebungen der Statischen Ämter kombiniert. Diese kombinierten Daten werden herangezogen um die Qualität der ProxyVariable Durchschnittslohnsatz zu überprüfen. Es wird einerseits gezeigt, dass dieser Durchschnittslohnsatz eine brauchbare Proxy-Variable für die Belegschaftsqualifikation ist. Andererseits wird aber auch gezeigt, dass die detaillierten Informationen über die Qualifikationsstruktur der Beschäftigten neue Einsichten über die Bedeutung von hochqualifizierten Arbeitskräften für den Erfolg auf Auslandsmärkten vermitteln. Dies ist wichtig, denn verlässliche Informationen über die Eigenschaften exportierender und nicht-exportierender Firmen und über die Beziehungen zwischen Firmeneigenschaften und dem Exportanteil am Umsatz sind von entscheidender Bedeutung für ein besseres Verständnis einer zentralen Dimension der Firmenperformance. Darüber hinaus können sie hilfreich sein für eine sachgerechte politische Diskussion um die Reduktion von Einwanderungsbarrieren für hoch qualifizierte ausländische Arbeitskräfte.

Damit wird deutlich, dass Datensätze für deutsche Unternehmen, in denen Informationen aus Erhebungen der Statistischen Ämter und Informationen aus der Statistik der sozialversicherungspflichtig Beschäftigten kombiniert werden, für wissenschaftliche Forschung und Politikberatung sehr wertvoll sein können. Sie sollten daher in Zukunft für Wissenschaftler breit zugänglich gemacht werden.

\section{References}

Alda, H., Bender, S., Gartner, H.: The linked employer-employee dataset created from the IAB establishment panel and the processproduced data of the IAB (LIAB). Schmollers Jahrb. Wirtsch.Soz.wiss. 125(2), 327-336 (2005)

Bernard, A.B., Wagner, J.: Export entry and exit by German firms. Rev. World Econ. 137(1), 105-123 (2001)
Conover, W.J.: Practical Nonparametric Statistics, 3rd edn. Wiley, New York (1999)

Delgado, M.A., Farinas, J.C., Ruano, S.: Firm productivity and export markets: a non-parametric approach. J. Int. Econ. 57(2), 397-422 (2002)

Fischer, G., Janik, F., Müller, D., Schmuckler, A.: The IAB establishment panel-things users should know. Schmollers Jahrb. Wirtsch.- Soz.wiss. 129(1), 133-148 (2009)

Helpman, E.: Understanding Global Trade. Harvard University Press, Cambridge (2011)

Hethey-Maier, T., Seth, S.: Das Betriebs-Historik-Panel (BHP) 1975-2008. Handbuch Version 1.0.2, FDZ-Datenreport 04/2010. Forschungsdatenzentrum der Bundesagentur für Arbeit im Institut für Arbeitsmarkt- und Berufsforschung, Nürnberg (2010)

Klein, M.W., Moser, C., Urban, D.: The contribution of trade to wage inequality: the role of skill, gender, and nationality. NBER working paper No. 15985, May (2010)

Malchin, A., Voshage, R.: Official firm data for Germany. Schmollers Jahrb. Wirtsch.- Soz.wiss. 129(3), 501-513 (2009)

Melitz, M.J.: The impact of trade on intra-industry reallocations and aggregate industry productivity. Econometrica 71(6), 1695-1725 (2003)

Munch, J.R., Skaksen, J.R.: Human capital and wages in exporting firms. J. Int. Econ. 75(2), 363-372 (2008)

Papke, L.E., Wooldridge, J.M.: Econometric methods for fractional response variables with an application to $401(\mathrm{k})$ plan participation rates. J. Appl. Econom. 11(6), 619-632 (1996)

Schank, T., Schnabel, C., Wagner, J.: Do Exporters really pay higher wages? First evidence from German linked employer-employee data. J. Int. Econ. 72(1), 52-72 (2007)

Schank, T., Schnabel, C., Wagner, J.: Higher wages in exporting firms: self-selection, export effect, or both? First evidence from linked employer-employee data. Rev. World Econ. 146(2), 303 $322(2010)$

Spengler, A.: The establishment history panel. Schmollers Jahrb. Wirtsch.- Soz.wiss. 128(3), 501-509 (2008)

Syverson, C.: What determines productivity? J. Econ. Lit. 49(2), 326$365(2011)$

Wagner, J.: A note on the firm size-export relationship. Small Bus. Econ. 17(4), 229-237 (2001)

Wagner, J.: Exports and productivity: a survey of the evidence from firm-level data. World Econ. 30(1), 60-82 (2007)

Wagner, J.: Estimated capital stock values for German manufacturing enterprises covered by the cost structure surveys. Schmollers Jahrb. Wirtsch.- Soz.wiss. 130(3), 403-408 (2010)

Wagner, J.: Exports and firm characteristics in German manufacturing industries: new evidence from representative panel data. Appl. Econ. Q. Manuscript, Leuphana University Lüneburg, August (2011a, forthcoming)

Wagner, J.: The quality of the KombiFiD-sample of enterprises from manufacturing industries: evidence from a replication study. University of Lüneburg Working Paper Series in Economics No. 217, November. Schmollers Jahrb. Wirtsch.-Soz.wiss. (2011b, forthcoming)

Wagner, J.: International trade and firm performance: a survey of empirical studies since 2006. Rev. World Econ. (2012) 148(2), 235267

Prof. Dr. Joachim Wagner is Professor of Economics at the Leuphana University Lüneburg. He is a research fellow at IZA and an editor of Schmollers Jahrbuch/Journal of Applied Social Science Studies, Jahrbücher für Nationalökonomie und Statistik/Journal of Economics and Statistics and the Journal for Labour Market Research/Zeitschrift für ArbeitsmarkForschung. Furthermore, he is a member of the German Data Forum (RatSWD). He published widely in economics journals; the topics include international firm activities and issues related to labor markets and industrial relations. Most of his papers use longitudinal data for firms for micro-econometric investigations. 